\title{
What Determines Expenditure Allocation to Beef among Lusaka Residents in Zambia? Evidence from Household Survey
}

\author{
Timothy Sichilima1, Lawrence Mapemba1, Gelson Tembo ${ }^{2,3}$ \\ ${ }^{1}$ Department of Agricultural and Applied Economics, Lilongwe University of Agricultural and Natural Resources, \\ Lilongwe, Malawi \\ ${ }^{2}$ Department of Agricultural Economics and Extension, University of Zambia, Lusaka, Zambia \\ ${ }^{3}$ School of Business Studies, University of Lusaka, Lusaka, Zambia \\ Email: tsichilima@gmail.com, Imapemba@gmail.com, tembogel@gmail.com
}

Received 24 February 2015; accepted 18 March 2015; published 24 March 2015

Copyright (C 2015 by authors and Scientific Research Publishing Inc.

This work is licensed under the Creative Commons Attribution International License (CC BY).

http://creativecommons.org/licenses/by/4.0/

(c) (i) Open Access

\begin{abstract}
This study uses data on 2585 households from the 2010 living conditions monitoring survey (LCMS) and a double-hurdle model to identify factors that affect household decisions on the level of beef expenditure among Lusaka residents. The results confirm that rural households make expenditure decisions that are significantly different from urban households. The results also reveal that factors such as income, size of the household, price of beef, price of chicken and education level of the household head are important determinants that influence both the decision to purchase beef and the level of beef expenditure. Thus, policy design needs to recognize these factors. Policies that aim to target urban households, for example, could increase beef consumption.
\end{abstract}

\section{Keywords}

Expenditure Allocation, Lusaka, Beef, Double Hurdle

\section{Introduction}

Beef, meat obtained from matured cattle, is a major source of animal protein and many other nutrients much needed by the human body; such as vitamins and minerals like phosphorus, sodium, iron, zinc, potassium and thiamine [1]. Protein is needed for both growth and repair of human body cells. Nutritionists have posited that animal proteins contain a complete set of amino acids as opposed to plant proteins [2]. Over the recent few decades, beef has witnessed global increase in demand as a result of increase in population, improvement in technology

How to cite this paper: Sichilima, T., Mapemba, L. and Tembo, G. (2015) What Determines Expenditure Allocation to Beef among Lusaka Residents in Zambia? Evidence from Household Survey. Modern Economy, 6, 411-422.

http://dx.doi.org/10.4236/me.2015.63039 
and increasing incomes [3] [4]. A healthy person in developing countries requires an average of 35 grams of animal protein intake per day [5].

Cattle and dairy products industry contributes approximately 3.2 per cent of Zambia's gross domestic product (GDP) [6]. In 2008, Zambia produced 58,400 metric tons of beef at a value of approximately US\$194 million [7]. The number of cattle in Zambia was estimated to be around 3.49 million in 2008, of which 83 per cent national herd was under the traditional sub-sector, while 17 per cent was reared under the commercial sub-sector [8]. Zambia is home to seven (7) large beef processing companies, with Zambia beef Company (Zambeef) as the leader. Zambeef commands 48 per cent of urban beef sales and 24 per cent share of the national beef market [7]. Butcheries have a market share of 66 per cent whilst the informal market has 22 per cent. Butcheries and the informal market are the major retail outlets for meats while supermarkets account for only 8 per cent market share [9]. Given the strong and growing regional market for beef and dairy products, there are good opportunities to expand Zambia's beef and dairy industries.

Poultry continues to be the primary meat consumed in Zambia, accounting for an estimated 50 per cent of total meat consumption followed by beef at 28 per cent, pork and fish at 16 per cent and others at 6 per cent [10]. Nevertheless, livestock products and fish form an important component of urban households' diets in Zambia together accounting for almost one third of households' monthly budgetary expenditure on food [9].

A number of studies have been done using household data to understand factors affecting household consumption decisions regarding beef as well as other meat types. Martinez et al. [11] looked at the factors affecting the demand for branded beef in the United States of America using a panel data set, which ranged from 1998 to 2004. They evaluated the growth of branded beef sales against household expenditures and described the characteristics of consumers purchasing branded beef products using a logit model on the 2004 data set. The study helped to identify specific target market groups for beef producers. This information is particularly important as it provides opportunities for branded beef alliances to enter programs that satisfy the growing demand for branded beef in a relatively cost-efficient manner, and increase returns to stakeholders. However, the study used the panel data for summary descriptive statistics instead of rigorous econometric modelling techniques in understanding consumers' expenditure pattern on branded beef. This might not provide relevant policy implication. [2] and [1] examined the expenditure pattern of beef in Nigeria using a double log and log linear model respectively. The study keyed out the influence of socio economic factors that influenced the monthly consumption of meat products by households. [2] specifically found that meat preference could be attributed largely to taste and habits; but less associated with socio-economic factors. Despite the models used being flexible and implying constant elasticities i.e. between price and income [12], they cannot capture zero expenditures [13]. A recent study by Aepli \& Finger [14] estimated the influence of different meat prices, socio-demographic and geographic variables on sheep and goat meat demand using a Tobit-model. The study found that socio-demographic variables and geographic variables are important in determining demand of sheep and goat meat. Nonetheless, such an analysis assumes that the factors that affect the decision to consume meat products are the same as the factors that influence the extent of consumption. This can underestimate the impact of the explanatory variables on food expenditures [15]. Moreover consumption has been observed to be a two-step process [16]-[18]. For instance the decision of whether or not to consume and how much to consume can be determined by different socioeconomic factors. In 2012, a study was commissioned to determine urban consumption patterns of livestock products in Zambia and implications for policy [9]. The study described consumption expenditures and also factors influencing the households' probability of purchasing various livestock products using a Probit Model.

However, factors that influence the residents' expenditure allocation on beef as well as extent of this allocation are not documented. This additional information is important for the government, small scale and commercial beef producers as well as marketers [8]. This is because low consumption of animal protein can pose a threat to market demand for beef [1] given the significant contribution the livestock sector makes to the Zambian economy [6]. Our study aims to identify the factors that influence Lusaka residents' expenditure allocation on beef. Knowledge of factors affecting Lusaka residents' food expenditure will provide insights which will allow the concentration of efforts on factors that can strengthen the livestock sector and result in increased earnings for the producers, marketers and government. This could help increase beef production and reduce prices, which should consequently result in increased consumption of beef. To the best of our knowledge, no such study has been done in Lusaka.

The remainder of this paper is organized as follows. The next section provides an overview of the methodology used to estimate factors that influence Lusaka residents' expenditure allocation on beef. This will be followed by 
a description of the sample data and the descriptive statistics for the selected variables. Section four provides a summary of empirical results and main findings along with a brief discussion of the policy implications. The conclusion and recommendations are provided in Sections five and six respectively.

\section{Methodology}

\subsection{Theoretical Framework}

A consumer is assumed to maximize a utility function subject to a monetary budget constraint [19]. Thus the consumer demand for a market good can be shown as a function of the price of the good and other similar goods, household income, taste and preferences and other socioeconomic factors [20] [21]. This study follows the works of Davis et al. [22] on demand analysis. Food demand system describes how the households make decisions on how much of their total income (expenditure) is to be allocated for food consumption, conditional on household characteristics [23].

According to [24] the utility function can be given as $U(x, q)$ where $x$ is the vector of quantities consumed and $q$ is a vector of factors affecting the consumption of a good. Following Nicholson \& Snyder [25], the consumer utility maximization problem can be expressed as:

$$
\operatorname{Max} U(x, q)=u\left(x_{1}, x_{2}, \cdots, x_{n}, q\right),
$$

Subject to total expenditure;

$$
M-p_{1} x_{1}-p_{2} x_{2}-\cdots-p_{n} x_{n}=0,
$$

where $M$ is total expenditure, and $p$ is a vector of prices if an individual chooses to maximize utility from $n$ goods. Therefore, the Lagrangian can be expressed as;

$$
\ell=U\left(x_{1}, x_{2}, \cdots, x_{n}\right)+\lambda\left(M-p_{1} x_{1}-p_{2} x_{2}-\cdots-p_{n} x_{n}\right),
$$

where $\lambda$ is the Lagrangian multiplier. Differentiating the Lagrangian with respect to the commodities, i.e. $x_{i}$, and setting the partial derivative of the Lagrangian to zero, the necessary conditions for an interior maxima for a corner solution can be expressed as;

$$
\frac{\partial \ell}{\partial x_{i}}=\frac{\partial U}{\partial x_{i}}=-\lambda p_{i} \leq 0 .
$$

Thus first-order conditions can give rise to a Marshallian demand for a good $i\left(x_{i}^{m}\left(p_{i}, q\right)\right)$ where $q$ represents social economic factors affecting the consumption of beef by Lusaka residents. Therefore the utility-maximization model can be used to derive demand for good $x_{i}$ when $p_{i}$ changes. Furthermore, the individual's expenditure function can be shown as the minimum expenditure needed to achieve a given utility level for a particular set of prices,

$$
\text { min exp enditure }=E\left(p_{1}, p_{2}, \cdots, p_{n}, U\right) .
$$

Therefore utility maximization can be associated to a dual minimization problem concerning the allocation of income in achieving a given utility level with minimal expenditure.

More explicitly the expenditure function can be expressed as;

$$
E_{i j}=f\left(Y_{j}, \text { HHsize }_{j}, P_{i}, \text { Educ }_{j}, Z_{j}\right), \quad i=1, \cdots, n
$$

where $E_{i j}=j$ th household's expenditure on $i$ th market food, $Y_{j}=$ the $j$ th household's measure of income, HHsize $=$ $j$ th Household size, $P_{i}=$ the vector of market prices faced by the $j$ th household, Educ ${ }_{j}=$ education level of the $j$ th household head and $Z_{j}=$ A set of other social economic and demographic factors for the $j$ th household and household head (age, gender, residence etc.).

The variable $Y_{j}$ reflects the basic economic condition of the household. Since consumption expenditure of a household on food is highly correlated with the purchasing power of the household [22], it is hypothesized that household money income $\left(Y_{j}\right)$ would positively affect household expenditure $\left(E_{i j}\right)$ on beef.

Household size is included to capture variations in household size that may very well have an effect on food consumption [26] [27]. It is generally accepted that as the household size gets larger, expenditure on food also increases. Therefore our study hypothesizes that household size would positively impact food expenditures. 
It has further been observed that welfare is sensitive to food price changes [28]. The prices of complementary and substitute goods such as chicken, goat meat, mutton, pork and fish are also included as these might also affect the expenditure on beef. Thus price has been incorporated in Equation (6) to capture the effect of price on households' expenditure. We hypothesize that price will negatively affect households' beef expenditure.

This study also hypothesize that age would have a positive effect on food consumption expenditure. It has been posited that diets change as people age, due to factors such as food availability, new information, new cumulative experiences, and physiological changes as bodies mature [29].

Our study further hypothesizes that gender would have an effect on food consumption expenditure. It is assumed that the gender of the household head has a significant role to play in food purchasing and would therefore influence tastes and preferences of the household members. For instance, Arganini et al. [30] and Prättälä et al. [31] reported that generally women are more likely to prefer much more health-promoting behaviours towards food than men.

Location of the household (Urban or Rural) is also hypothesized to have an effect on the consumption expenditure of the household. Urban residents may have a broader choice of food types and easy access to food markets [32]. This might not be the case for rural households who might have to depend much on their own production.

Education has also been included because it has a significant influence on food expenditure. For instance education has been found to play a role in shaping consumers' purchasing decisions regarding food [33] [34]. Education can act as a proxy for perceived nutritional knowledge about the food. It is hypothesized that education will have an effect on food expenditure.

\subsection{Empirical Framework}

A double-hurdle model was used in this study to identify the factors that influence Lusaka residents' expenditure on beef. Because our dependent variable is heavily censored at zero, ordinary least squares (OLS) would not yield consistent estimates [17]. Thus the standard Tobit model can be used to overcome or accommodate the censoring in the dependent variable. However, this model is considered very restrictive, as it assumes that the determinants of expenditure extent are the same as the determinants of participation [35] [36]. A double hurdle model is used in such cases to overcome this restriction. The double hurdle model involves modeling a binary decision, in the first hurdle, regarding whether or not to allocate expenditure to beef; and modeling the level of beef expenditure when above zero in the second hurdle. A different latent variable is used to model each decision process, with a probit formulation (first hurdle) explaining the participation decision (whether to allocate expenditure to beef) and a truncated regression model (second hurdle) explaining the extent of expenditure allocation. Algebraically, these decisions can be represented as:

$$
\begin{aligned}
& y_{i 1}^{*}=Z_{i}^{\prime} \alpha+v_{i}, \text { Participation Decision } \\
& y_{i 2}^{*}=X_{i}^{\prime} \beta+\mu_{i}, \text { Expenditure Decision } \\
& y_{i}=X_{i}^{\prime} \beta+\mu_{i}, \text { If } y_{i 1}^{*}>0 \text { and } y_{i 2}^{*}>0 \\
& y_{i}=0, \text { Otherwise }
\end{aligned}
$$

where $y_{i 1}^{*}$ is a latent variable describing the household's decision to participate in the beef market and $y_{i 2}^{*}$ is a latent variable describing household's expenditure on beef, $y_{i}$ is the observed dependent variable (households' expenditure allocation on beef), $Z_{i}$ is a vector of variables explaining the participation decision, $X_{i}$ is a vector of variables explaining the expenditure decision, $v_{i}$ and $\mu_{i}$ are the respective error terms assumed to be independent and distributed as $v_{i} \sim N(0,1)$ and $\mu_{i} \sim N\left(0, \sigma^{2}\right)$. The observation $i$ is only observed if $y_{i 1}^{*}$ is above a certain known threshold which is a zero in this case.

Models of this nature are heavily reliant on the assumption of normality in the error terms [18]. When this assumption breaks down the maximum likelihood estimates will be inconsistent. A number of approaches have been attempted to transform the dependent and latent variables to accommodate the breakdown of the normality assumption [36]. Following Barungi et al., (2013) and allowing for non-normality of the error structure and heteroskedasticity, the likelihood function for the truncated regression model can be expressed as: 


$$
L(\alpha, \beta, \theta)=\prod_{y_{i}=0}\left[1-\Phi\left(z_{i}^{\prime} \alpha\right) \Phi\left(\frac{x_{i}^{\prime} \beta}{\sigma_{i}}\right)\right] \prod_{y_{i}>0}\left[\left(1+\sigma^{2} y_{i}^{2}\right)^{-1 / 2} \Phi\left(z_{i}^{\prime} \alpha\right) \sigma_{i}^{-1} \phi\left(\frac{T\left(\theta y_{i}\right)-x_{i}^{\prime} \beta}{\sigma_{i}}\right)\right],
$$

where $\phi$ and $\Phi$ respectively are the probability density function and the cumulative density function of the standard normally distributed random variable.

It was also observed from Ayuya [37] and Yen \& Huang [18] that the extent of expenditure allocation conditional on participation through the assessment of the impact of regressors on the extent of consumption using partial effects can be given as:

$$
E\left(y_{i} \mid y_{i}>0\right)=\Phi\left(\frac{x_{i}^{\prime} \beta}{\sigma_{i}}\right)^{-1} \int_{0}^{\infty}\left(\frac{y_{i}}{\sigma_{i}} \phi\left(\frac{T\left(y_{i}\right)-x_{i}^{\prime} \beta}{\sigma_{i}}\right) \frac{1}{1+\theta^{2} y_{i}^{2}}\right) \mathrm{d} y_{i} .
$$

Generally prices will be expected to have a negative effect on consumption decision [14]. This is because an increase in the price of beef can lead to lower demand (Table 1). It is also expected that household size would have a negative effect on participation and a positive effect on how much is spent on beef. This is because an increase in household size by one person would probably make it expensive to spend on beef; a household with a bigger number of members might not purchase beef. For instance, Worako [38] found a negative relationship

\begin{tabular}{|c|c|c|}
\hline Variable & Description & Expected sign \\
\hline \multicolumn{3}{|l|}{ Dependent variables } \\
\hline Participation decision & If the Lusaka resident participated in beef consumption (Yes = 1, No =0). & \\
\hline $\begin{array}{l}\text { Beef expenditure } \\
\text { (extent decision) }\end{array}$ & $\begin{array}{l}\text { This will be a continuous variable of how much expenditure was allocated towards } \\
\text { the purchase of beef. }\end{array}$ & \\
\hline \multicolumn{3}{|l|}{ Independent variables } \\
\hline Price of beef & The price of beef in Zambian Kwacha per kilogram & - \\
\hline Price of fish & The price of fish in Zambian Kwacha per kilogram & \pm \\
\hline Price of chicken & The price of chicken in Zambian Kwacha per kilogram & \pm \\
\hline Price of pork & The price of pork in Zambian Kwacha per kilogram & \pm \\
\hline Price of goat meat & The price of goat meat in Zambian Kwacha per kilogram & \pm \\
\hline Price of mutton & The price of mutton in Zambian kwacha per kilogram & \pm \\
\hline Household size & The number of household members in the family & \pm \\
\hline Residence & Residence $($ Urban = 1, Rural = 0) & + \\
\hline Married & Marital status of household head; dummy, $1=$ married, $0=$ otherwise & \pm \\
\hline Medium cost area & Type of residential area; dummy, 1 = Medium cost, 0 = otherwise & \pm \\
\hline High cost area & Type of residential area; dummy, $1=$ High cost, $0=$ otherwise & + \\
\hline Primary Education & Attended primary school; dummy, 1 = attended primary school, 0 = otherwise & + \\
\hline Secondary Education & Attended secondary education; dummy, 1 = attended secondary school, 0 = otherwise & + \\
\hline Tertiary Education & Attended tertiary education; dummy, 1 = attended tertiary education, 0 = otherwise & + \\
\hline Household income & $\begin{array}{l}\text { Income will be used in the context of total household expenditure, proxy for current } \\
\text { income }\end{array}$ & + \\
\hline Gender of the household head & If the decision maker is male or female (dummy; Male $=1,0$ otherwise & \pm \\
\hline Age of household head & Age of the household head in years & + \\
\hline Household asset value & The value of assets owned by the household head & + \\
\hline
\end{tabular}

Table 1. Categories and definitions of independent variables used in the model. 
between household size and the likelihood of a household to participate in beef consumption whereas the expected positive sign on the effect of household size on beef expenditure is supported by [1] who found that household size had a positive effect on how much beef is purchased. Marital status would be a dummy of whether the household head is married or not. Other studies have found marital status to be related to the dietary patterns of households [39]. It is envisaged that a married respondent would participate in consumption but the effect of how much is spent on beef consumption would be either positive or negative [18]. Education is expected to have a positive effect on both participation and expenditure allocation on beef. Borrowing from Akinbode [16] findings, education had a positive effect on both participation and expenditure allocation on fresh fish in Nigeria. Income in our study would be used in the context of total household expenditure. Fu et al., (2013) found a positive impact of income on cookie consumption as well as participation in Kampala, Uganda. This implies that household income is a significant factor in influencing the level of food consumption. This is also supported by [1], who found a positive relationship between household income and beef expenditure. This might be attributed to high propensity to consume in developing countries. It is expected that residence (urban) would have a positive effect on both participation and how much is allocated on beef. That is urban dwellers have a higher propensity to consume beef and might also spend more on beef than their rural counterparts. [32] found a positive effect of urban location on beef expenditure. This partly reflects the greater propensity to consume by urban residents encouraged by higher incomes and greater access to food markets. This supports Obayelu et al. [40] finding on the effect of rural households on food consumption where a negative effect of rural households on both participation and level of expenditure on fruits and vegetables was observed. Rural households rely more on their own production. It is expected that age would have a positive effect on both participation as well as expenditure allocation on beef. This is taken up from Meenaksh et al., [27] who found that age has a positive effect on purchasing decision regarding food items.

\section{Data}

Zambia's 2010 Living Conditions Monitoring Survey (LCMS) data were used. The nationally representative survey had a total sample size of 20,000 households distributed across 1000 standard enumeration areas (SEAs). The study used a two-stage cluster sampling procedure in which the first stage involved selection of primary sampling units (PSUs) or SEAs using probability proportional to estimated size (PPES) from a national sampling frame developed during the 2000 Census of population and housing. The second stage then involved using systematic sampling to select the sample households in the SEAs that had been selected in the first stage. The sampling frame for the second stage was developed through a comprehensive listing exercise. This study is based on a sub-sample of 2585 Lusaka residents.

During the 2000 census, the country was administratively demarcated into 9 provinces, which were further sub-divided into 72 districts. The districts were further subdivided into a total of 150 constituencies, which were in turn divided into wards. For the purposes of facilitating Central Statistical Office (CSO) surveys, wards were further divided into Census Supervisory Areas (CSA), which were further subdivided into Standard Enumeration Areas (SEAs). SEAs constitute the Primary Sampling Units (PSUs). The allocation of the sample points to rural and urban strata was done in such a way that it was proportional to their sizes in each district.

\section{Results and Discussion}

Table 2 indicates that the average expenditure on beef was ZMW 22.556 at an average price of ZMW 12.35 per kilogram. This implies that on average, households purchase slightly less than $2 \mathrm{~kg}$ of beef per month; the household expenditure on beef was measured on a four week period. The average prices for potential substitutes and complementary goods i.e. fish, chicken, pork, goat meat and mutton were ZMW 15.60, ZMW 15.15, ZMW 15.75, ZMW 15.71 and ZMW 15.98, respectively. This reveals that beef fetches a lower price compared to other meat alternatives. This can be attributed to the competitiveness of the product in urban areas [9]. The mean size of households was about 5 persons. Sampled households had an average income of ZMW 1611 with age of household heads ranging from 18 to 90 years of age. About 45 per cent of the sampled households had household heads who had attained secondary education compared to 22 per cent household head who had attained primary education. This implies that less than 30 per cent of households sampled had members who had attained tertiary education. Nevertheless, Less than 10 per cent of the households were from high cost areas. Most of the households sampled came from low and medium cost areas. This is commensurate with status of the country 
Table 2. Summary of descriptive statistics of some variables studied.

\begin{tabular}{|c|c|c|c|}
\hline Variable & Mean & Minimum & Maximum \\
\hline Price of Beef $\left(\mathrm{ZMW}^{1} / \mathrm{Kg}\right)$ & 12.35 & 1.67 & 27.32 \\
\hline Price of fish (ZMW/kg) & 15.60 & 10 & 34.2 \\
\hline Price of chicken (ZMW/kg) & 15.15 & 1 & 15.8 \\
\hline Price of pork (ZMW/kg) & 15.75 & 7.49 & 27.32 \\
\hline Price of goat (ZMW/Kg) & 15.71 & 2.5 & 97.99 \\
\hline Price of mutton (ZMW/Kg) & 15.98 & 10.76 & 21.76 \\
\hline Expenditure on beef & 22.556 & 0 & 2640 \\
\hline Residence, $(1=$ urban (\%), 0 = rural) & $82 \%$ & 0 & 1 \\
\hline Household size & 4.912 & 1 & 25 \\
\hline Medium cost area (\%) & $17 \%$ & 0 & 1 \\
\hline High cost area (\%) & $8 \%$ & 0 & 1 \\
\hline Married (\%) & $68 \%$ & 0 & 1 \\
\hline Age of household head in years & 40.45 & 18 & 90 \\
\hline Primary education (\%) & $22 \%$ & 0 & 1 \\
\hline Secondary education (\%) & $45 \%$ & 0 & 1 \\
\hline Tertiary (\%) & $26 \%$ & 0 & 1 \\
\hline Household Income (ZMW) & 1611 & 0 & 90,000 \\
\hline Gender $(1=$ male $(\%), 0=$ female $)$ & $77 \%$ & 0 & 1 \\
\hline Value of assets in ZMW & 38,000 & 0 & $4,069,225$ \\
\hline
\end{tabular}

Data Source: LCM survey, 2010; ${ }^{1}$ The estimated exchange rate was at ZMW 6.2 per US\$ (http://www.boz.zm/).

being low income; most households reside in low cost areas and this has implications on food purchasing decisions. Generally, the sampled households had more male-headed households compared to female-headed households; about 23 percent households were female-headed. This implies that males dominate household-decision making in urban areas. The study further found that more than 30 percent of households sampled had household heads who were not married. In terms of asset ownership, the average value of assets owned was ZMW 38,000. Assets are a proxy for wealth and contribute towards wealth accumulation.

The relationship between beef expenditure and household characteristics was gleaned from the results of Cragg's analysis presented in Table 3. The prices of beef, fish and chicken were found to be significant with both beef and fish bearing negative coefficients. A 10 per cent increase in the price of beef and fish would lead to a $0.08^{1}$ and 0.04 per cent reduction in the expected mean consumption of beef and fish, respectively. However, a 10 per cent increase in the price of chicken would lead to an increase in the expected mean consumption of beef by 0.09 per cent. This entails that even though the price of beef forms an integral part in attracting consumers to purchase beef, small price increases by themselves have a measly effect on beef consumption. Slight increases in the price of beef would not lure Lusaka residents into consuming more beef. This is consistent with [24] findings. Generally, consumption of beef was found to be much less responsive to prices of chicken and fish. On the other hand, the prices of beef and chicken were found to be significant in determining the allocation of expenditure on beef. A ZMW 1 increase in the price of beef would lead to a 17 ngwee $^{2}$ reduction on beef expenditure. This can be attributed to the majority of households in the sample coming from low and medium cost areas; beef for such households can be an expensive food item. In contrast, a ZMK 1 increase in the price of

\footnotetext{
${ }^{1} \log$ of Price of beef $\times \ln (1.10)=-0.814 \times \ln (1.1)=0.07796$.
}

${ }^{2}$ A Zambian monetary unit worth one hundredth of a kwacha. 
Table 3. Cragg's model results.

\begin{tabular}{|c|c|c|c|c|}
\hline \multirow[b]{2}{*}{ Variables } & \multicolumn{2}{|c|}{ First Hurdle } & \multicolumn{2}{|c|}{ Second Hurdle } \\
\hline & Marginal Effects & Standard Error & $\begin{array}{c}\text { Average Partial } \\
\text { Effects }\end{array}$ & Standard Error \\
\hline Log of Price of beef (ZMW/Kg) & $-0.814^{* * *}$ & 0.050 & $-16.989^{* * *}$ & 6.299 \\
\hline Log of Price of fish (ZMW/Kg) & $-0.410^{* *}$ & 0.210 & 2.328 & 5.392 \\
\hline Log of Price of chicken (ZMW/Kg) & $0.947^{* * *}$ & 0.058 & $22.842^{* * *}$ & 7.682 \\
\hline Log of Price of pork (ZMW/Kg) & -0.135 & 0.207 & -0.055 & 5.027 \\
\hline Log of Price of goat meat (ZMW/Kg) & -0.164 & 0.132 & -3.874 & 3.51 \\
\hline Log of Price of mutton (ZMW/Kg) & -1.553 & 2.400 & 26.170 & 55.402 \\
\hline Urban dummy, 1 = urban & $0.190^{* * *}$ & 0.039 & $8.345^{* * *}$ & 2.351 \\
\hline Household size & $-0.016^{* *}$ & 0.007 & $0.674^{* * *}$ & 0.178 \\
\hline \multicolumn{5}{|c|}{ Residence dummy $(1=$ yes; base $=$ low-cost areas $)$} \\
\hline Medium cost area & $-0.119^{* * *}$ & 0.045 & $3.187^{* *}$ & 1.228 \\
\hline High cost area & 0.010 & 0.065 & 1.729 & 1.547 \\
\hline \multicolumn{5}{|c|}{$\begin{array}{l}\text { Level of education attained by the household head } \\
(1=\text { yes; base = no education })\end{array}$} \\
\hline Primary education & 0.114 & 0.081 & $-16.938^{* * *}$ & 2.232 \\
\hline Secondary education & 0.101 & 0.074 & $-7.850^{* * *}$ & 1.801 \\
\hline Tertiary education & 0.014 & 0.07665 & $3.837^{* *}$ & 1.874 \\
\hline Married & 0.021 & 0.049 & 1.139 & 1.223 \\
\hline Age of household head in years & $0.006^{* * *}$ & 0.002 & $0.120^{* *}$ & 0.059 \\
\hline Log of Household Income (ZMW) & $0.140^{* * *}$ & 0.008 & $4.873^{* * *}$ & 1.263 \\
\hline Sex of household head, $1=$ male & $-0.154^{* * *}$ & 0.056 & -2.334 & 1.728 \\
\hline Log of Value of assets in ZMW & -0.008 & 0.007 & $2.981^{* * *}$ & 0.296 \\
\hline Pseudo R2 & 0.650 & & & \\
\hline Log likelihood & -614.473 & & -6718.677 & \\
\hline Sigma constant & & & $411.474^{* * *}$ & 62.213 \\
\hline Observations & 2585 & & 2585 & \\
\hline LR and Wald chi2(18) & $2351.28^{* * *}$ & & $841.080^{* * *}$ & \\
\hline
\end{tabular}

Data Source: LCM survey, 2010; ${ }^{* * *},{ }^{* *}$ and ${ }^{*}=$ significance of $1 \%, 5 \%$ and $10 \%$ respectively.

chicken would lead to a 23 ngwee increase in the expenditure on beef. The findings that chicken is a good substitute for beef is consistent with the conclusions in Davis et al. [41] who studied complements and meat demand in the US using a Heckeman two step procedure. The demand for beef was found to be significantly related to the demand for poultry.

Residence was positive and significant as a determinant of the likelihood of spending on beef. A household located in the urban residence was more likely to allocate expenditure on beef than a household located in the rural residence. On average, being in urban residence would increase the probability to allocate expenditure on beef by about 19 per cent higher than rural residents, ceteris paribus. This affirms [32] and Yen \& Huang [18] findings that urban residents were more likely to engage in fish and beef expenditure respectively. Unlike urban households, rural households have alternative non-market means of accessing animal protein. For example, mice 
and insects are some common forms of animal protein among rural dwellers which are hunt in the bush by rural household for which case they are rarely registered as part of household consumption expenditure. While in urban areas, households mostly access animal protein via the market, for which case a household is likely to spend on beef should it prefer to take animal protein. Given that households allocated expenditure on beef, urban households are likely to allocate more on beef by ZMW 8.345 on average compared to rural households.

Household size was an important determinant in household's probability and decision to allocate expenditure on beef. The probability of a household participating in the consumption of beef was significant and negative. This entails that an increase in household size by one person would decrease the probability of a household to allocate expenditure on beef by $1.6 \%$. This is also implied by the idea that the larger the family size the more the beef quantity it needs and hence the more expensive it is to procure beef. The coefficient of household size for the level of beef expenditure was positive and significant implying that for each added member to the household, a household would switch to less expensive alternative relish i.e. dried fish, sardines. Given that a household decides to allocate expenditure on beef, an addition member to a household could cost 67 ngwee. This is consistent with Worako [38] findings that household size was negatively related with meat demand. Consumption of high value foods such as beef is partly affected by family size; that is, when family size is large it's unlikely to regularly consume high value foods mainly due to its implication on budget.

Medium cost areas had a significant effect on the probability of allocating expenditure on beef. Medium cost areas were less likely to spend on beef by 12 per cent compared to low cost areas. This might imply that increasing levels of affluence in medium cost areas would lead to less consumption of beef in preference to other types of meat such as chicken. Nevertheless, given that a medium cost household allocated expenditure on beef, its expenditure allocation on beef would cost more by ZMW 3.18 on average compared to low cost households. This could be attributed to subsistence levels of households in low cost areas compared to medium cost areas which might prompt them to spend proportionately more on food.

The impact of education on the probability to allocate expenditure on beef was insignificant. However, given that a household head allocated expenditure on beef, attaining primary and secondary education decreases the beef expenditure by ZMW 16.98 and 7.85, respectively. In contrast, attaining tertiary education increased beef expenditure allocation by ZMW 3.83 compared to a household head with no education. This result corroborate that of Akbay [42] and Wang et al. [43] who found that individuals with higher education tend to increase consumption of animal products.

The effect of age on the probability allocating expenditure on beef was significant. The coefficient of the age of the household head for the level of beef expenditure was positive and significant. An increase in the age of the household head by a year increases the probability of expenditure on beef by 0.6 per cent. Age of the household head would increase beef expenditure by 12 ngwee. This is consistent with Yakaka et al. [44] findings that age has positive and significant relationship with expenditure on ruminant meat.

The results also show that income has a positive and significant effect on the household's likelihood to allocate expenditure on beef. A 10 per cent increase in the household income would lead to a 1.3 per cent increase on beef expenditure. Thus an increase in household income has the edge to increase household's expenditure on beef. A ZMW1 increase in income would lead to a 5 ngwee increase in expenditure on beef. This implies that the higher the income level, the higher the expenditure on beef. Ceteris paribus, income is one of the key determinants of budget share allocation among households. Nevertheless, this corroborates with [32] findings who showed that income played a positive role in beef expenditure. Beef is a normal good; therefore, the positivity of the coefficient means consumers will increase their expenditure on beef so long as incomes increase.

Being male decreases the probability of allocating expenditure on beef. Being a male household head decreases the probability of allocating expenditure on beef by 15 per cent. This result contrasts with Rimal \& Fletcher [45] finding that male respondents were more likely to consume beef compared to females. This contrast could be attributed to the unequal sample size in males against females as household heads. For instance, over 70 percent of sampled households in Lusaka had males as household-heads.

The value of household assets was found to be insignificant in influencing household's decision to allocate expenditure on beef. This is also a proxy for accumulation of wealth. However, given that a household allocated expenditure on beef, ZMW1 increase in the value of household assets would increase the amount spent on beef by 3 ngwee.

However, factors such as goat meat price, price of pork, price of mutton, being married and living in a high cost area did not have an effect on households' decision to allocate expenditure on beef and let alone level of 
expenditure on beef. However, Sanusi \& Adewoyin [46] found marriage in Nigeria to be a factor in influencing household preference for beef; demand for beef was learnt to be high amongst married household heads. In this study, price of goat meat, price of pork, price of mutton had a negative effect on household's decision to allocate expenditure on beef. This entails a complementary relationship with beef. This is consistent with findings by Aepli and Finger [14] who found complementarity among prices of beef, mutton and goat meat. The coefficient of being married and residing in high cost areas had a positive effect on the household's likelihood to allocate expenditure on beef. With regard to extent of expenditure, price of pork and goat meat had a negative effect on the level of beef expenditure. However, price of mutton, being married and residing in high cost areas had a positive effect on the level of expenditure on beef.

\section{Conclusions}

Beef is one of the essential food products in a modern balanced diet. It provides the much needed animal proteins to non-vegetarian population in Lusaka and Zambia at large. The study has revealed that a number of socioeconomic variables affected the probability of households' decision in allocating expenditure on beef. For instance, urban dwellers were more likely to allocate a part of their expenditure on beef compared to rural households. Therefore, this calls for a need to target urban areas if beef consumption is to be increased. On the other hand, consumer demand for beef was found to be inelastic with respect to price of beef, chicken and fish. However, beef was found to be a significant substitute for chicken. This entails that a significant increase in the price of beef could result into Lusaka residents switching to its alternative, chicken.

Nevertheless, the positive effect of income, higher education and urban residence on level of beef expenditure imply that demand for beef will increase with income, higher education and targeting of urban residences, respectively. Therefore the increasing urbanization and population attaining higher education could generate promising market segments for beef; urbanization has the potential of making beef prices competitive. The findings of this study offer a promising picture for the future of the livestock industry and its supplying industries. The identification of these factors equips marketers, small and commercial producers of beef with information that can help them in developing a niche in the Lusaka market considering the current low consumption of beef in Zambia.

\section{Recommendation}

Government should boost cattle production in the country through efforts such as subsidizing animal feeds to beef producers, help in the improvement of technology in livestock feed to reduce cost of feed, increase access to credit and own farm production of feed which might have a significant effect on beef production. It is further recommended that the society should be enlightened on the nutritional value of beef with special emphasis targeted on people with low education.

\section{References}

[1] Ekine, D.I., Albert, C.O. and Peregba, T.A. (2012) Expenditure Pattern for Beef Consumption in Selected Households in Southern Nigeria. Developing Country Studies, 2, 1-5.

[2] Alimi, S.R. (2013) Households Expenditure Pattern on Beef and Chicken of Selected Households in Akoko SouthWest LGA of Ondo State. Munich Personal RePEc Archive Paper No. 52153.

[3] Dafwang, I.I., Ikam, E.I., Chikwendu, D.O., Adeshinwa, A.O.K., Annate, A.I. and Iwuanyanwu, I.E.J. (2001) Adoption of Non-Conventional Feedstuffs by Poultry and Pig Farmers in Nigeria. Proceedings of the 26th Annual Conference of the Nigerian Society for Animal Production, 254-257.

[4] Food and Agriculture Organization (2012) Statistical Yearbook. Food and Agriculture Organization of the United Nations Regional Office for Africa.

[5] Omolaran, A.B. (2004) Intra-Household Redistribution of Income and Calorie Consumption in South-Western Nigeria. Economic Growth Center Discussion Paper No. 890, Yale University, New Haven.

[6] Lubungu, M. and Mukuka, M.R. (2012) The Status of the Smallholder Livestock Sector in Zambia. Technical Report 1 submitted to the Parliamentary Committee on Agriculture. Indaba Agricultural Policy Research Institute, Lusaka.

[7] World Bank (2011) What Would It Take for Zambia’s Beef and Dairy Industries to Achieve Their Potentials? Department for International Development, UKaid. 
[8] Chikazunga, D., Ndiyoi, M. and Muloongo, O. (2008) Restructuring Food Markets in Zambia: Dynamics in the Beef and Chicken Sub-Sectors. Policy Brief 9. Regoverning Markets.

[9] Hichaambwa, M. (2012) Urban Consumption Patterns of Livestock Products in Zambia \& Implications for Policy. Working Paper for Indaba Agricultural Policy Research Institute, Lusaka.

[10] Ngosa, M. (2011) Commercial Agribusiness and Value Chains. Agribusiness Congress Lusaka 2011, Zambia.

[11] Martinez, S., Hanagriff, R., Lau, M. and Harris, M. (2007) Factors Affecting Demand for Branded Beef. Proceedings of the Southern Agricultural Economics Association Annual Meetings, Mobile, 4-6 February 2007, 14.

[12] Gujarati, D.N. (2008) Basic Economics. Fifth Edition, Tata McGraw-Hill Publishing Company Limited, New Delhi.

[13] Blundell, R., Pistaferri, L. and Preston, I. (2005) Imputing Consumption in the Psid Using Food Demand Estimates from the Cex. Working Paper 04/27, The Institute for Fiscal Studies, London.

[14] Aepli, M. and Finger, R. (2013) Determinants of Sheep and Goat Meat Consumption in Switzerland. Agricultural and Food Economics, 1, 11. http://dx.doi.org/10.1186/2193-7532-1-11

[15] Reynolds, A. (1990) Analyzing Fresh Vegetable Consumption from Household Survey Data. Southern Journal of Agricultural Economics, 22, 31-38.

[16] Akinbode, S.O. and Dipeolu, A.O. (2012) Double-Hurdle Model of Fresh Fish Consumption among Urban Households in South-West Nigeria. Current Research Journal of Social Sciences, 4, 431-439.

[17] Wan, W. and Hu, W. (2012) At Home Seafood Consumption in Kentucky: A Double-Hurdle Model Approach. Proceedings of the Southern Agricultural Economics Association Annual Meeting, Birmingham, AL, 4-7 February 2012, 119-807.

[18] Yen, S.T. and Huang, C.L. (1996) Household Demand for Finfish: A Generalized Double-Hurdle Model. Journal of Agricultural and Resource Economics, 21, 220-234.

[19] McCracken, V.A. and Brandt, J.A. (1987) Household Consumption of Food-Away-from-Home: Total Expenditure and by Type of Food Facility. American Journal of Agricultural Economics, 69, 274-284. http://dx.doi.org/10.2307/1242277

[20] Lancaster, K. (1966) A New Approach to Consumer Theory. Journal of Political Economy, 74, 132-157. http://dx.doi.org/10.1086/259131

[21] Meng, T., Florkowski, W.J., Kolavaliiand, S. and Ibrahim, M. (2012) Food Expenditures in Rural Households in the Northern Region of Ghana. Proceedings of the Southern Agricultural Economics Association Annual Meeting, Birmingham, AL, 4-7 February 2012, 2-13.

[22] Davis, C.G., Moussie, M., Dinning, J.S. and Christakis, G.J. (1983) Socioeconomic Determinants of Food Expenditure Patterns among Racially Different Low-Income Households: An Empirical Analysis. Western Journal of Agricultural Economics, 8, 183-196.

[23] Blundell, R., Pashardes, P. and Weber, G. (1993) What Do We Learn about Consumer Demand Patterns from Micro Data? American Economic Review, 83, 570-597.

[24] Tonsor, G., Mintert, J. and Schroeder, T. (2009) US Beef Demand Drivers and Enhancement Opportunities. Kansas State University Agricultural Experiment Station and Cooperative Extension Service.

[25] Nicholson, W. and Snyder, C. (2008) Microeconomic Theory: Basic Principals and Extensions. 10th Edition, Thomson South-Western, Mason.

[26] Hymans, S.H. and Shapiro, H.T. (1975) The Allocation of Household Income to Food Consumption. Journal of Econometrics, 4, 167-188. http://dx.doi.org/10.1016/0304-4076(76)90011-7

[27] Meenakshi, J.V. and Ray, R. (2000) Impact of Household Size and Family Composition on Poverty in Rural India. Journal of Policy Modeling, 24, 539-559.

[28] Alem, Y. and Söderbom, M. (2011) Household-Level Consumption in Urban Ethiopia: The Effects of a Large Food Price Shock. Department of Economics, University of Gothenburg, Sweden and School of Economics, Addis Ababa University, Ethiopia.

[29] Wendt, M. and Kinsey, J. (2007) Do Eating Patterns Follow a Cohort or Change Over a Lifetime? Answers Emerging from the Literature. The Food Industry Center Working Paper 2007-01, University of Minnesota, Minneapolis, 1-38.

[30] Arganini, C., Saba, A., Comitato, R., Virgili, F. and Turrini, A. (2012) Gender Differences in Food Choice and Dietary Intake in Modern Western Societies. In: Maddock, J., Ed., Public Health-Social and Behavioral Health, InTech, 8495.

[31] Prättälä, R., Paalanen, L., Grinberga, D., Helasoja, V., Kasmel, A. and Petkeviciene, J. (2006) Gender Differences in the Consumption of Meat, Fruit and Vegetables Are Similar in Finland and the Baltic Countries. European Journal of Public Health, 17, 520-525. http://dx.doi.org/10.1093/eurpub/ckl265 
[32] Liu, H., Parton, K.A., Zhou, Z. and Cox, R. (2005) Away-from-Home Meat Consumption in China. Asian Journal of Agriculture and Development, 8, 83-97.

[33] Binkley, J. and Golub, A. (2010) Household Food Choice in Four Food Categories: Healthy or Unhealthy? Working Paper \#10-2. Department of Agricultural Economics, Purdue University, West Lafayette.

[34] Hogan, J.J. and Berning, J.P. (2012) Estimating the Relationship between Education and Food Purchases among Food Insecure Households. Proceedings of the Agricultural \& Applied Economics Association's 2012 AAEA Annual Meeting, Seattle, 12-14 August 2012, 1-32.

[35] Burke, W.J. (2009) Fitting and Interpreting Cragg's Tobit Alternative Using Stata. The Stata Journal, 9, 584-592.

[36] Keelan, C.D., Henchion, M.M. and Newman, C.F. (2006) A Double Hurdle Model of Irish Households' Foodservice Expenditure Patterns. Proceedings of the 98th EAAE Seminar. Marketing Dynamics within the global Trading System: New Perspectives, Crete, 29 June-2 July 2006, 1-19.

[37] Ayuya, O.I. (2010) Evaluation of Willingness to Accept and Adopt Clean Development Mechanism Projects among Small-Scale Farmers in Njoro District, Kenya. Unpublished Master’s Dissertation, Egerton University, Nairobi.

[38] Worako, T.K. (2009) Analysis of Changes in Food Consumption Pattern in Urban Ethiopia. Paper Submitted for the Seventh International Conference on the Ethiopian Economy, Addis Ababa, 24-26 June 2010, 1-4.

[39] Kroshus, E. (2008) Gender, Marital Status, and Commercially Prepared Food Expenditure. Journal of Nutrition Education and Behavior, 40, 355-360. http://dx.doi.org/10.1016/j.jneb.2008.05.012

[40] Obayelu, A.E., Okoruwa, V.O. and Oni, O.A. (2009) Analysis of Rural and Urban Households’ Food Consumption Differential in the North-Central, Nigeria: A Micro-Econometric Approach. Journal of Development and Agricultural Economics, 1, 18-26.

[41] Davis, C., Stefanova, S., Hahn, W. and Yen, S. (2008) Complements and Meat Demand in the US. Proceedings of the American Agricultural Economics Association Annual Meeting, Orlando, 27-29 July 2008, 2-13.

[42] Akbay, C., Boz, I. and Chern, S.W. (2007) Household Food Consumption in Turkey. European Review of Agricultural Economics, 34, 209-231. http://dx.doi.org/10.1093/erae/jbm011

[43] Wang, J.M., Zhou, Z.Y. and Young, J. (2004) How Much Animal Product Do the Chinese Consume? Empirical Evidence from Household Survey. Australian Agribusiness Review, 12, 1-16.

[44] Yakaka, B.M., Iheanacho, A.C. and Kabagana, K. (2011) Determinants of Ruminant Meat Demand among Different Income Groups in Maiduguri, Borno State, Nigeria. AGRIS On-Line Papers in Economics and Informatics, Volume 4, Number 4.

[45] Rimal, A.P. and Fletcher, S.M. (2003) Understanding Consumers’ Attitude toward Meat Labels and Meat Consumption Pattern. Proceedings of the Southern Agricultural Economics Association Annual Meeting, Mobile, Alabama, 1-5 February 2003, 1-19.

[46] Sanusi, W.A. and Adewoyin, J.A. (2014) Analysis of Consumer Preference for Meat Types in Ogbomoso Metropolis of Oyo State, Nigeria. Journal of Agriculture Economics and Rural Development, 2, 16-20. 